Jurnal Info Kesehatan

Vol.18, No.1, June 2020, pp.68-73

P-ISSN 0216-504X, E-ISSN 2620-536X

DOI: 10.31965/infokes.Vol18.Iss1.392

Journal homepage: http://jurnal.poltekeskupang.ac.id/index.php/infokes

R E S E A R C H

\title{
Effectiveness of Breadfruit Leaf Extract (Artocarpus Altilis) as a Mouthwash to Reduce Saliva Viscosity
}

\author{
Wiworo Haryani ${ }^{1 a^{*}}$, Siti Hidayati ${ }^{1 \mathrm{~b}}$, Lusi Khasanah ${ }^{\text {1c }}$ \\ ${ }^{1}$ Department of Dental Health, Poltekkes Kemenkes Yogyakarta, Indonesia \\ a Email address: haryaniwiworo@gmail.com \\ ${ }^{\mathrm{b}}$ Email address: jkg.hidayati@gmail.com \\ c Email address: khasanahlusi@yahoo.com
}

Received: 23 March 2020

Revised: 26 June 2020

Accepted: 27 June 2020

\begin{abstract}
Saliva is a complex liquid in the mouth that has an important role as self cleansing. If the viscosity of saliva is getting lower, the possibility of caries will decrease. The use of mouth rinses is one way to maintain oral hygiene. One of the herbs that can be used as medicine is breadfruit leaf (Artocarpus Altilis). The objective of this study is to determine the effect of breadfruit leaf extract (Artocarpus Altilis) as a mouthwash on saliva viscosity in boarding students of the Dental Nursing Department. This type of research is a pre-experiment with the design of One Group Pretest Posttest which was conducted in October-November 2019. The population of this research study was the boarding students of the Dental Nursing Department of the Yogyakarta Health Polytechnic Ministry of Health with a sample size of 40 respondents taken by purposive sampling technique. Data analysis used Paired Sample T-Test and Simple Linear Regression. $62.5 \%$ of respondents aged 18 years with female sex were more than men that were $97.5 \%$. The parametric test results using Paired Sample T-Test showed a significant difference with a value of $p=0.000$. Simple Linear Regression analysis test results showed that there was a significant influence between the accumulation of salivary viscosity before and after gargling the breadfruit leaf extract (Artocarpus Altilis) concentration of $20 \%$, with a decrease in the means before gargling the breadfruit leaf extract 3.5810 to 2.6025 with a significance value $0.004(\mathrm{P}<0.05)$. The conclusion of this study is that there is an influence of breadfruit leaf extract (Artocarpus Altilis) as a mouthwash on saliva viscosity in boarding students of the Dental Nursing Department. It is recommended for further research on the use of breadfruit leaf extract (Artocarpus Altilis) as a mouthwash with different concentrations and solvents so as to increase knowledge of the effectiveness of breadfruit leaves as a mouthwash ingredient.
\end{abstract}

Keywords: Saliva Viscosity, Breadfruit Leaves

\footnotetext{
*Corresponding Author:

Wiworo Haryani

Department of Dental Health, Poltekkes Kemenkes Yogyakarta

Kyai Mojo Street, No. 56, Yogyakarta, Central Java, Indonesia

Email: haryaniwiworo@gmail.com

(C)The Author(s) 2020. This article is distributed under the terms of the Creative Commons Attribution 4.0

International License (http://creativecommons.org/licenses/by/4.0/), which permits unrestricted use, distribution, and reproduction in any medium, provided you give appropriate credit to the original author(s) and the source, provide a link to the Creative Commons license, and indicate if changes were made. The Creative Commons Public Domain Dedication waiver (http://creativecommons.org/publicdomain/zero/1.0/) applies to the data made available in this article, unless otherwise stated.
} 
Haryani, W., Hidayati, S., \& Khasanah, L. (2020). Effectiveness of Breadfruit Leaf Extract (Artocarpus Altilis) as a Mouthwash to Reduce Saliva Viscosity. JURNAL INFO KESEHATAN, 18(1), 68-73. https://doi.org/10.31965/infokes.Vol18.Iss1.392

\section{INTRODUCTION}

The results of the Basic Health Research in 2018 showed that the proportion of dental and oral health problems was $57.6 \%$ and those receiving services from dental medical personnel were $10.2 \%$. The proportion of teeth brushing behavior correctly was $2.8 \%$. Seen from the age group, the young age group experienced more dental caries compared to the age $\geq 45$ years. Age 10-24 years of dental caries is $66.8-69.5 \%$, age $\geq$ 45 years $53.3 \%$ and age $\geq 65$ years by $43.8 \%$. This situation shows that many dental caries occur in the productive age group (Kementerian Kesehatan, R. I., 2018). Dental caries is a multi-factor process that occurs through interactions between teeth and saliva as hosts, bacteria in the oral cavity, and easily fermented food. Saliva is a complex fluid found in the oral cavity composed of a mixture of salivary glands (Lima et al, 2010). Saliva is one of the factors having a major influence on the severity of dental caries (Ramadan, 2010).

The environment or saliva has an important role, because saliva functions as self cleansing, maintaining the health of soft and hard tissue that is in the oral cavity, lubrication, antimicrobial and buffer capacity. There are four factors that affect the quality of this saliva, comprising of the level of acidity $(\mathrm{pH})$, bulk saliva, volume and viscosity (Ristianti et al., 2015). Viscosity is a measure of the viscosity of a liquid. Viscosity is strongly influenced by mucins due to the presence of high molecular glycoproteins in it. At rest, the viscosity of saliva is viscous so that it can flow and last long enough in the oral cavity whereas in the oral cavity function, the viscosity of saliva in a dilute state so as to provide good lubrication in the oral cavity (Rahmawati et al., 2016). If the viscosity of saliva is getting lower, the possibility of caries will decrease, because when viscosity is low, the flow or volume and volume of saliva will increase. Hence, salivary content such as lysozyme which functions as an antibacterial will also increase (Kusuwardani E., 2011). If the viscosity increases, the composition of water in the saliva decreases and this will cause the saliva to become thicker (Affianti, 2010).

The use of mouthwash is one of the methods quite successful in maintaining oral hygiene, the drug that is often used is an antiseptic mouthwash, but the use of antiseptic as a mouthwash can have a carcinogenic effect on its use. The use of traditional medicine has evolved as a safer alternative to chemicals (Ristianti et al., 2015). Herbal mouthwash is safer than chemical mouthwash. Ingredients containing herbal mouthwash are natural and contain no alcohol, artificial preservatives, flavoring agents and colorants (Phatak et al., 2011). Plants that are believed to be used as medicine are breadfruit (Artocarpus Altilis) which is an herbal plant that has many benefits. Breadfruit plants have a variety of benefits, all of these plant parts have been used as traditional medicine, especially the leaves (Ratna, 2018). Breadfruit leaves contain several nutritious substances such as saponins, polyphenols, hydroxyic acid, acetylcolin, tannins, riboflavin and phenol. Flavonoid compounds function as chemicals to overcome disease attacks as antimicrobial or antibacterial (Rasyadi, 2018, Yuliastri, W. O., \& Prasetyo, M., 2019).

Previous studies relating to the effectiveness of breadfruit leaf extracts are associated with the growth of Streptococcus mutants bacterial colonies, whereas this study is different from previous studies that are associated with saliva viscosity. The objective of this study is to determine the effect of giving breadfruit leaf extract (Artocarpus Altilis) as a mouthwash on saliva viscosity. Herbal mouthwash has many pharmacological effects as anti-inflammatory, antimicrobial, and anticariogenic. The benefits of this study are as an alternative to the use of safer herbal mouthwash. 


\section{RESEARCH METHOD}

This type of research is a Pre-Experiment research with a One Group Pretest Posttest design. The population in this study was students in dormitory 2 Department of Dental Nursing Health Polytechnic Ministry of Health Yogyakarta, with 40 respondents selected by purposive sampling. The inclusion criterion is applied undergraduate student dormitory 2 Department of Dental Nursing Health Polytechnic Ministry of Health Yogyakarta 17-20 years old, do not have systemic diseases such as diabetes, kidney, heart and asthma. Exclusion criteria: using prostheses and orthodontic devices, taking oral drugs and systemic antibiotics, were not present in the study. The time of the study was in October-November 2019.

The type of data used consisted of primary and secondary data. Primary data was data obtained directly by observing and interviewing students at the Dental Nursing Department of Yogyakarta Health Polytechnic Health Ministry. Secondary data is data obtained from the board of directors of the Dental Nursing Department. Data collection techniques were performed using a saliva viscosity inspection sheet. The independent variable is breadfruit leaf extract with $70 \%$ ethanol solvent so that it becomes a thick extract. Then, the thick extract was diluted using aquades to $20 \%$ breadfruit leaf extract concentration. The dependent variable is the saliva viscosity, which is the value of saliva viscosity (dyne/cm3) measured using the ostwald viscometer. Making breadfruit leaf extract (Artocarpus Altilis) is performed by maceration method using $70 \%$ ethanol solvent, liquid extract is filtrated 3 times to obtain a thick extract made into a concentration of $20 \%$ using aquades. Saliva collection was conducted in the morning 2 times, which was before and after gargling $10 \mathrm{ml}$ of breadfruit leaf extract (Artocarpus Altilis). Measurements were made 2 times, before and after gargling with breadfruit leaf extract (Artocarpus Altilis). The controlled variable was breadfruit leaf extract concentration of $20 \%$ by $10 \mathrm{ml}$, while the uncontrolled variable was dental caries.

Analysis in this study used the Paired Sample $\mathrm{T}$ test and Simple Linear Regression test. Paired Sample T-Test is to determine differences in salivary viscosity before and after gargling breadfruit leaf extract (Artocarpus Altilis) and Simple Linear Regression test to determine the effect of breadfruit leaf extract (Artocarpus Altilis) as a mouthwash on saliva viscosity. This research has been declared ethical by the Health Research Ethics Commission (KEPK) of the Health Ministry of Health, Yogyakarta No. e-KEPK/POLKESYO/0324/X/2019.

\section{RESULTS AND DISCUSSION}

Table 1. Frequency Distribution of Respondents by Age and Gender.

\begin{tabular}{lrr}
\hline Respondent Frequency Distribution & Number & \multicolumn{2}{r}{ Percent $(\%)$} \\
\hline Age (year) & 1 & 2,5 \\
\hline 17 & 25 & 62,5 \\
\hline 18 & 12 & 30 \\
\hline 19 & 2 & 5 \\
\hline 20 & $\mathbf{4 0}$ & $\mathbf{1 0 0}$ \\
\hline Total & & 2,5 \\
Gender & 1 & 97,5 \\
\hline Male & 39 & $\mathbf{1 0 0}$ \\
\hline Female & $\mathbf{4 0}$ & \\
\hline
\end{tabular}


Haryani, W., Hidayati, S., \& Khasanah, L. (2020). Effectiveness of Breadfruit Leaf Extract (Artocarpus Altilis) as a Mouthwash to Reduce Saliva Viscosity. JURNAL INFO KESEHATAN, 18(1), 68-73. https://doi.org/10.31965/infokes.Vol18.Iss1.392

71

Table 1 shows that the most respondents aged 18 years were 25 people $(62.5 \%)$, while the respondents who were female were more than men, which were 39 people $(97.5 \%)$.

Table 2. Paired Sample T test results difference in average viscosity of saliva before and after gargling breadfruit leaf extract (Artocarpus Altilis).

\begin{tabular}{|c|c|c|c|c|c|}
\hline Saliva viscosity & Mean & SD & $\mathbf{t}$ & df & $\mathbf{p}$ \\
\hline Before gargling breadfruit leaf extract & 3,581 & & 6,318 & 39 & 0,000 \\
\hline After gargling the breadfruit leaf extract & 2,602 & & & & \\
\hline
\end{tabular}

Table 2 shows the results of the Paired Sample T-test indicating that there was a significant difference in the average viscosity of saliva before and after gargling the breadfruit leaf extract (Artocarpus Altilis) with a p value $=0.000$.

Table 3. Results of analysis of the Simple Linear Regression test before and after gargling of breadfruit leaf extract (Artocarpus Altilis).

\begin{tabular}{cccc} 
Variable & Coefficients & \multicolumn{1}{l}{ t } & \multicolumn{1}{l}{ Sig. } \\
\hline After gargling the breadfruit leaf extract & $-3,62$ & 3,079 & 0,004
\end{tabular}

Table 3 results of simple linear regression analysis results show that the magnitude of the effect of mouth rinse extract of breadfruit leaves on the viscosity of saliva obtained regression coefficient number -3.62 shows that there is a negative effect after rinse of breadfruit leaf extract on saliva viscosity, namely a decrease in saliva viscosity by 3.62 with value of $p=0.004$.

Lower salivary viscosity will increase the rate of salivary flow so that a good self cleansing effect is obtained to reduce the risk of dental caries (Sulendra et al., 2013). High viscosity of saliva (thick) causes the saliva flow rate will be lower and there is a buildup of leftovers that cause caries, so prevention is needed by using mouthwash. The results of this study are supported by Sa'diah \& Hayati (2018) who stated that the role of saliva as a lubricant is very important for oral health, which helps the movement of the tongue and lips during the process of chewing and swallowing and to clarify speech.

In this study, breadfruit leaf extract was used with a concentration of $20 \%$. It is in line with research Ratna, (2018) that the physical properties of mouthwash concentrations of $10 \%, 15 \%$ and $20 \%$ provide good results and met the requirements of mouthwash preparations. Breadfruit leaves have inhibitory effects on the growth of Streptococcus mutants. The antibacterial and antimicrobial content of breadfruit leaves (Artocarpus Altilis) can inhibit the growth of Streptococcus mutants' bacteria that cause dental caries (Bempa, 2016).

Breadfruit leaf extract has antibacterial properties by inhibiting some extract concentrations. The stronger the inhibitory power, the higher the concentration of the extract sensitivity to microbial growth, and the greater the diameter of the inhibition against the Staphylococcus aureus bacteria (Sucy, 2014, Suryanto, E., \& Wehantouw, F., 2019). The higher the number of dental caries, the thicker the viscosity of saliva because the content of lysozyme in saliva which functions as an antibacterial decreases, so prevention is needed by using mouthwash in order to increase saliva production and viscosity (Sariyem at al., 2015). The difficulty in this study is that the viscometer ostwald is not clearly visible so it can affect the recording of salivary flow times.

The use of $70 \%$ ethanol as a solvent in this study to improve the effectiveness of breadfruit leaf extraction (Verdiana et al., 2018) that a compound will be dissolved in a 
solvent with the same properties. Breadfruit leaves contain various antibacterial compounds such as flavonoids, phenols, alkaloids and tannins (Rosmawaty \& Tehubijuluw, 2013). Flavonoids include natural phenolic compounds that have potential as antioxidants and have bioactivity as a drug (Una, 2010). Breadfruit leaf flavonoids compound is also as anti-inflammatory, anti-oxidant, anti-platelet, anti-cancer, antidiabetes and anti-atherosclerosis (Rizema, 2013). The flavonoid compounds contained in the breadfruit leaf extract are polar so that we need a polar solvent that is also ethanol. The results of this study indicate that breadfruit leaf extract can be used as an alternative mouthwash ingredient from herbal ingredients because it has antibacterial and antimicrobial properties that can inhibit the growth of bacteria that cause dental caries.

\section{CONCLUSION}

There is an influence of the use of breadfruit leaf extract (Artocarpus Altilis) as a mouthwash on saliva viscosity. Breadfruit leaf extract (Artocarpus Altilis) can reduce the viscosity of saliva. Suggestions for further research is the use of breadfruit leaf extract (Artocarpus Altilis) as a mouthwash with different concentrations and solvents so as to increase knowledge of the effectiveness of breadfruit leaves as a mouthwash ingredient.

\section{REFERENCES}

Affianti, H. S. (2010). Viskositas Saliva Sebelum dan Setelah Mengunyah Buah Apel dan Minum Jus Apel Pada Mahasiswa FKG USU Angkatan 2006-2007. Skripsi: Universitas Sumatra Utara Medan.

Bempa, S. L. P., Fatimawali., Parengkuan W. G. (2016). Uji Daya Hambat Ekstrak Daun Sukun (Artocarpus altilis) terhadap Pertumbuhan Bakteri Streptococcus mutans. Pharmacon Jurnal Ilmiah Farmasi, 5(4), 1-9.

Kementerian Kesehatan RI. (2018). Riset Kesehatan Dasar (Riskesdas) 2018. Jakarta: Badan Penelitian dan Pengembangan Kesehatan Kementerian Kesehatan RI

Kusuwardani, E. (2011). Buruknya Kesehatan Gigi dan Mulut. Yogyakarta: Siklus.

Lima, D. P., Diniz, D. G., Moimaz, S. A. S., Sumida, D. H., \& Okamoto, A. C. (2010). Saliva: reflection of the body. International Journal of Infectious Diseases, 14(3), e184-e188. DOI: https://doi.org/10.1016/j.ijid.2009.04.022

Phatak, A. A., Patankar, R. D., Galgatte, U. C., Paranjape, S. Y., Deshpande, A. S., Pande, A. K., \& Thombre, R. (2011). Antimicrobial activity of a poly-herbal extract against dental micro flora. Res J Pharm Biol Chem Sci, 2(2), 533-539.

Ramadhan, A. G. (2010). Serba serbi kesehatan gigi dan mulut. Jakarta: Kawah Media.

Ristianti, N., W, J. K., \& Marsono. (2015). Perbedaan Efektifitas Obat Kumur Herbal Dan Non Herbal Terhadap Akumulasi Plak Di Dalam Rongga Mulut. Jurnal Medali, 2(1), 31-36.

Rizema, S. (2013). Ajaibnya Daun Sukun Berantas Berbagai Penyakit. Yogyakarta: Flash Books.

Rahmawati, A. D., \& Hanafi, M. G. S. (2016). Perbedaan antara Kumur Ekstrak Siwak (Salvadora Persica) dan Kumur Infus Siwak terhadap Viskositas Saliva. Insisiva Dental Journal: Majalah Kedokteran Gigi Insisiva, 5(1), 1-9.

Ratna. (2018). Uji Efektivitas Mouthwash Ekstrak Daun Sukun (Artocarpus communis) terhadap Staphylococcus aureus. Jurnal Kesehatan, 2(1).

Rasyadi, Y. (2018). Formulasi sediaan kumur dari ekstrak daun sukun Artocarpus altilis (Parkinson ex FA Zorn) Fosberg. Chempublish Journal, 3(2), 76-84. https://doi.org/10.22437/chp.v3i2.5767 
Haryani, W., Hidayati, S., \& Khasanah, L. (2020). Effectiveness of Breadfruit Leaf Extract (Artocarpus Altilis) as a Mouthwash to Reduce Saliva Viscosity. JURNAL INFO KESEHATAN, 18(1), 68-73. https://doi.org/10.31965/infokes.Vol18.Iss1.392

Rosmawaty, R., \& Tehubijuluw, H. (2013). Screening of Phytochemicals and Bioactivity Test of The Leaves Breadfruit (Artocarpus altilis). Indo. J. Chem. Res., 1(1), 28-32.

Sa'diah, K., dan Hayati, M. (2018). Pengaruh Konsumsi Kopi (Coffea Sp) Terhadap Ph, Laju Alir Dan Viskositas Saliva Pada Pecandu Kopi (Coffee Holic). B-Dent: Jurnal Kedokteran Gigi Universitas Baiturrahmah,5(1), 72-82. DOI: https://doi.org/10.33854/JBDjbd.141

Sariyem, S., Sadimin, S., Sunarjo, L., \& Haniyati, M. (2015). Efektifitas Ekstrak Daun Sukun Hasil Perebusan Terhadap Pertumbuhan Koloni Bakteri Streptococcus Mutans. Jurnal Kesehatan Gigi, 2(2), 104-109.

Sulendra, K.T, Fatmawati, D.W.A, Nugroho, R. (2013). Hubungan pH dan Viskositas Saliva terhadap Indeks DMF-T pada siswa-siswi Sekolah Dasar Balebaru I dan Balebaru II Sukowono Jember. Artikel Ilmiah Hasil Penelitian Mahasiswa. Fakultas Kedokteran Gigi, Universitas Jember

Sucy L., (2014). Uji Daya Hambat Ekstrak Etanol Daun Sukun (Artocarpus altilis) terhadap Pertumbuhan Bakteri Staphylococcus aureus. Skripsi. Universitas Syiah Kuala Banda Aceh.

Suryanto, E., \& Wehantouw, F. (2019). Aktivitas penangkap radikal bebas dari ekstrak fenolik daun sukun (Artocarpus altilis F.). Chemistry Progress, 2(1), 1-7.

Una, M. (2010). .Daun Ajaib Tumpas Penyakit. Jakarta: Penebar Swadaya

Verdiana, M., Widarta, I.W.R.,Permana I.D.G.M. (2018). Pengaruh Jenis Pelarut pada Ekstraksi menggunakan Gelombang Ultrasonik terhadap Aktivitas Antioksidan Ekstrak Kulit Buah Lemon (citrus limon (Linn.) Burm F.). Jurnal Ilmu dan Teknologi Pangan, 7,(4), 213-222.

Yuliastri, W. O., \& Prasetyo, M. (2019). Formulasi Pasta Gigi Herbal Ekstrak Daun Sukun (Artocarpus Altilis) Dan Uji Aktivitas Antibakteri Terhadap Bakteri Streptococcus mutans. Jurnal Mandala Pharmacon Indonesia, 5(01), 10-14. 